九州大学学術情報リポジトリ

Kyushu University Institutional Repository

\title{
Changes in the Combustion Characteristics of Living Quercus Mongolica Leaves with Altitude Variation
}

Park, Young-Ju

School of Fire \& Disaster Prevention, Kangwon National University

Lee, Hae-Pyeong

School of Fire \& Disaster Prevention, Kangwon National University

Lee, Si Young

Professional Graduate School of Disaster Prevention, Kangwon National University

Cha, Joo Yanng

Field Science Center for Northern Biosphere, Hokkaido University

他

https://doi.org/10.5109/18832

出版情報: 九州大学大学院農学研究院紀要. 55 (2)，pp.215-219，2010-10-29. Faculty of Agriculture, Kyushu University

バージョン :

権利関係 : 


\title{
Changes in the Combustion Characteristics of Living Quercus Mongolica Leaves with Altitude Variation
}

\author{
Young-Ju PARK ${ }^{1}$, Hae-Pyeong LEE ${ }^{1}$,, Si Young LEE ${ }^{2}$, \\ Joo Young CHA ${ }^{3}$ and Shoji OHGA
}

\author{
Laboratory of Forest Resources Management, Division of Forest Environmental Sciences, \\ Department of Agro-environmental Science, Faculty of Agricultare, \\ Kyushu University, Sasaguri, Fukuoka 811-2415, Japan \\ (Received May 20, 2010 and accepted July 9, 2010)
}

\begin{abstract}
In this study, combustion tests were conducted on living $Q$. mongolica leaves to compare their combustion characteristics at different altitudes. Leaf moisture content was measured and combustion characteristics were then studied using an ignition temperature tester, a cone calorimeter, and a smoke density chamber. The samples contained $117-145 \%$ moisture. The temperature of non-flame ignition was $275-308{ }^{\circ} \mathrm{C}$ and did not vary with altitude. Samples from 1,300 $\mathrm{m}$ and 1,500 $\mathrm{m}$ ignited more quickly than the others, but went out after 2 and 4 seconds, respectively. Heat release increased and reached its peak at 1,100 m, thereafter decreasing. Smoke release decreased and smoke density increased in proportion to altitude. The mean release density of $\mathrm{CO}$ rose gradually with increasing altitude while that of $\mathrm{CO}_{2}$ increased from $1,200 \mathrm{~m}$.
\end{abstract}

\section{INTRODUCTION}

The gravity of forest fires are evaluated by representations of individual or synthetic dangerousness, which consist of several factors including topography, atmospheric phenomena, and fuel type, all of which affect the mechanisms of forest fire spread (Kim et al., 2006). Fuel, one of the elements affecting the mechanisms of forest fire spread, brings about various patterns and shapes of fire according to its kind and form. This leads to differences in complex combustion in terms of, e.g., ignition, smoke release, the rapidity of heat release, toxicity, and the amount of heat released (Davis et al., 1959). Hence, to predict fire intensity and fuel movement, one must survey the types and shape of fuel in a forest and analyze the combustion characteristics of flammable fuel. Furthermore, to confirm combustion characteristics systematically, research into the combustion characteristics of fuel according to the forest physiognomy of each region and the study of atmospheric phenomena and topographical peculiarities should be performed simultaneously.

Currently, a variety of disaster prevention measures are aimed at local and international forests. The system for rating forest fire dangerousness marks hazardous sections with four indices, which are helpful for the establishment of fire prevention projects. These indices are the artificial forest fire occurrence index, forest fire occurrence caused by lightning index, combustion index, and combustion amount index (Lee, 2004). To predict the level of dangerousness of surface fire fuel, some research on the quantification of forest fire intensity using the amount of heat per unit area has been undertaken.

${ }^{1}$ School of Fire \& Disaster Prevention, Kangwon National University, Samcheok, 245-711, Korea

${ }^{2}$ Professional Graduate School of Disaster Prevention, Kangwon National University, Samcheok, 245-711, Korea

Field Science Center for Northern Biosphere, Hokkaido University, Nayoro, 096-0071, Japan

* Corresponding author (E-mail: crelab@kangwon.ac.kr)
Recently, studies on the combustion characteristics of flammable material in a forest have been conducted in Korea (Kim et al., 1995; Kim et al., 1999; Park et al., 2007). Predicting the dangerousness of a forest fire to flammable material is difficult, as researchers and equipment cannot easily access and test the site of fires, and thus gathering data from indoor experiments is common (Jung et al., 2002; KS F 2271, 1998). However, locally adverse circumstances can prevent researchers from identifying combustion patterns through experiments, leading to incomprehensive studies. To examine systemic combustion mechanisms, various experiments based on chemical methods are needed.

A geographical feature of Korea is that the northeastern mountainous district has high altitudes, while the northwestern district contains extensive, low, gently rolling hills. Accordingly, vegetation distribution and structure varies according to altitude, and tree species and forest types are noticeably different between the two regions (Gangwon Provincial Police Agency, 2002). The forest zone of Korea is divided into tropical forest, temperate zone forest, and frozen zone forest. The representative species of temperate zone forests in Korea include Styrax japonica Sieb. et Zucc., Quercus serrata Thunb., Quercus mongolica Fischer, Juniperus chinensis Linn., Abies holophylla Maximowicz, Betula davurica Pall., and Pinus densiflora Sieb. et Zucc. (Yim, 2007).

In this study, tests on the combustion characteristics of fuel from various altitudes were conducted to compare the fire characteristics of forest fuels. Living $Q$. mongolica leaves were used as test fuel. The purpose of this research was to collect basic data to establish criteria for predicting the movement of forest fires by analyzing characteristics of ignition, fire, and smoke release.

$$
\text { MATERIALS AND METHODS }
$$

\section{Site selection}




\subsection{Study site and fuel}

Mt. Taeback (altitude, 1,567 m), in Gangwon Province, was chosen as the study site for this research, as it has the topographic characteristics and vegetation resources of the east coast area, where large-scale forest fires most frequently occur in Korea. Living leaves of Q. mongolica, which is the dominant oak in temperate zone forests, were selected as the test fuel, as this species occurs across a range of altitudes on the mountain. Fuel sampling was conducted by picking up seven samples on hiking trails every $100 \mathrm{~m}$ from altitudes of 900 to $1,500 \mathrm{~m}$. Living leaves were chosen as fuel to use the fuel type that would be naturally available during a forest fire.

\subsection{Measuring moisture content}

Before combustion characteristic tests were conducted, the moisture content of the sample fuel was measured. Moisture content was measured using formula (1) according to ASTM D2016 (American Society for Testing and Material) (Kim et al., 2004; Shim et al., 1994). A $200-\mathrm{g}$ sample was dried in a $103^{\circ} \mathrm{C}$ oven for 24 hours, and was then measured until it reached constant mass. The mean value of three measured values was used as the outcome value. Samples were collected in October, after 5 consecutive fine days. MC (moisture content) is the moisture content ratio [\%], W represents the weight of samples before drying [g], and W0 is the weight of dried samples.

$$
M C(\%)=\frac{W-W_{0}}{W_{0}} \times 100(\%)
$$

\subsection{Combustion characteristic tests}

To test the combustion characteristics of living $Q$. mongolica leaves with altitude variation, tests on the characteristics of ignition, fire, and smoke release were conducted. To analyze the characteristics of ignition, ignition temperature (IT), time to ignition (TTI) and time to flameout (TTF) were measured. For an analysis of fire characteristics, total heat release (THR) and mean heat release rate (mean HRR) were used, and for the characteristics of smoke release, total smoke release (TSR), maximum smoke density (max. Ds), and smoke temperature (Ts) were measured. The mean release densities of the combustion products $\mathrm{CO}$ and $\mathrm{CO}_{2}$ were also analyzed.

\section{Methods}

\subsection{Analysis of ignition characteristics}

To analyze ignition characteristics, non-flame IT was measured using an IT chamber (model number
KRS-RG-9000; Kuramochi Co., Japan; Hong et al., 1992). The time for flash ignition, when fuel was exposed to radiation, was recorded using a cone calorimeter. Flame close time, namely, the time when the fire was extinguished naturally, was measured and after-flame time was analyzed simultaneously. The presence or absence of a flame at flash ignition was recorded, as judged by the naked eye.

\subsection{Analysis of fire characteristics}

To examine fire characteristics, a dual cone calorimeter chamber (ISO 5660-1, 2002) of FTT Co., England was used to analyze the mean HRR. The experiment ended when the sample stopped decreasing in weight, and this value was chosen as the output value. The mean value of three replicates was used as the outcome value. The THR was calculated based on the accumulated value by integrating the heat release rate, represented by a function of time, per its sample's surface area. The mean HRR was calculated by dividing the THR by the given amount of time. The experimental conditions are presented in Table 1.

\subsection{Analysis of smoke release characteristics}

To analyze the characteristics of smoke release, a smoke density chamber (ASTM E 662, 2003) and cone calorimeter (FTT Co.) were used. TSR and Ts were measured with the cone calorimeter, and smoke density was analyzed using the smoke density chamber. Since TSR measured by the cone calorimeter is the total smoke occurrence per unit area according to ISO 5660-2 (ISO 5660-2, 2002), and as smoke occurs in proportion to area, a standard value related to the area was used.

The total smoke occurrence rate $\left(\mathrm{m}^{2}\right)$ was the value integrated by the time of smoke release $\left(\mathrm{m}^{2} / \mathrm{s}\right)$ in the related section. Ts was measured using a thermocouple when the smoke had passed through a 0.5-mW heliumneon laser in a duct. For the measurement of smoke density, a smoke density chamber was used, applying a vertical test of non-flaming. The mean value of three replicates was used as the outcome value. Experimental conditions are presented in Table 1.

\section{RESULTS AND DISCUSSION}

To compare the combustion characteristics of fuel from varying altitudes, combustion tests were conducted on living $Q$. mongolica leaves that were collected at 100-m altitude intervals on Mr. Taeback, Gangwon Province, Korea. The results were as follows.

Table 1. Experimental conditions for the smoke density chamber and cone calorimeter

\begin{tabular}{lcc}
\hline Items & Cone calorimeter & Smoke density chamber \\
\hline Size $(\mathrm{mm})$ & $100 \times 100$ & $75 \times 75$ \\
Weight $(\mathrm{g})$ & 50 & 10 \\
Heat flux $\left(\mathrm{kW} / \mathrm{m}^{2}\right)$ & 50 & 25 \\
Test time $(\mathrm{s})$ & the time until there is no & 1,200 \\
Material condition & more weight decrease & raw \\
\hline
\end{tabular}




\section{Moisture content characteristics}

Fig. 1 shows the moisture content curve of living $Q$. mongolica leaves with altitude variation. Leaves contained $117-145 \%$ moisture at various altitudes. Moisture contents at 1,300 $\mathrm{m}$ and 1,400 $\mathrm{m}$ were lower than at other altitudes. Leaves had moisture contents of 120.44, 130.71, $131.88,139.90,117.35,116.45$, and $144.72 \%$ from altitudes of $900,1,000,1,100,1,200,1,300,1,400$, and $1,500 \mathrm{~m}$, respectively.

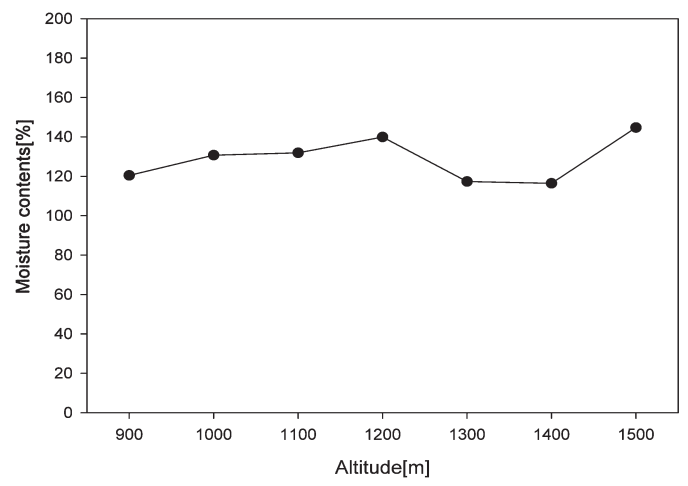

Fig. 1. Moisture content percentages of living Q. mongolica leaves from various altitudes.

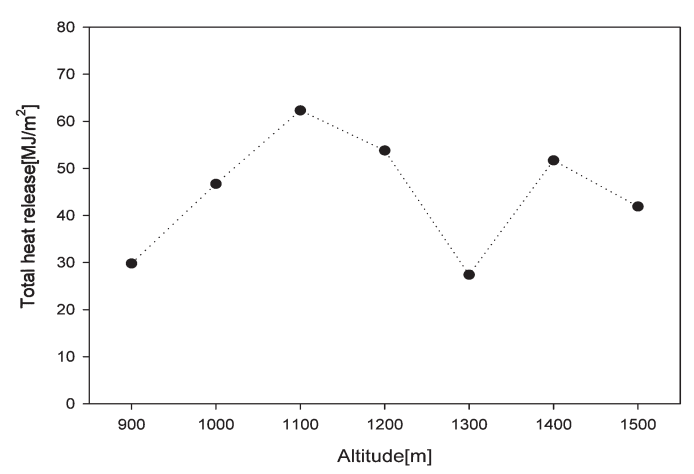

Fig. 2. Total heat release of living $Q$. mongolica leaves from various altitudes.

\section{Ignition characteristics}

Table 2 shows the ignition characteristics of living $Q$. mongolica leaves from various altitudes. The ITs in Table 2 indicate the non-flame IT temperature, which varied little from 275 to $308^{\circ} \mathrm{C}$. Samples from $1,100 \mathrm{~m}$ and $1,300 \mathrm{~m}$ had low ITs. When recording the TTI and TTF, the cone calorimeter used in this study measured only the flame ignition time, not non-flame ignition. Flame ignition time was recorded for all altitudes except $1,200 \mathrm{~m}$.

Although the flame ignition of the $1,200 \mathrm{~m}$ sample was not observed, the high heat release shown in Table 3 and the high TSR shown in Fig. 4 indicate that nonflame ignition occurred. Samples from 1,300 m and $1,500 \mathrm{~m}$ ignited faster than the other samples, but the flames faded away after 2 and 4 seconds, respectively. Conversely, the sample from $1,400 \mathrm{~m}$ had an ignition time of 59 seconds, but its flame was maintained for the longest of all samples.

\section{Fire characteristics}

Fig. 2 shows the curve of THR with altitude variation, and Fig. 3 shows the curve of the mean HRR. THR was $30-62 \mathrm{MJ} / \mathrm{m}^{2}$ and mean HRR was $12-33 \mathrm{~kW} / \mathrm{m}^{2}$. From 900 to $1,100 \mathrm{~m}$, heat release increased with altitude, with

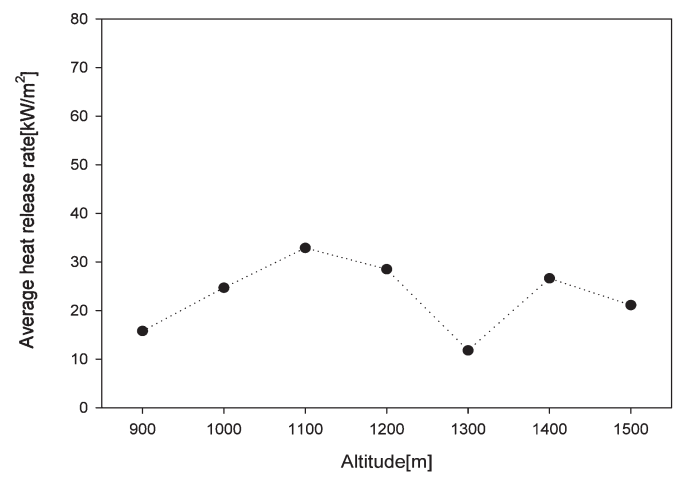

Fig. 3. Heat release rate of living $Q$. mongolica leaves from various altitudes.

Table 2. Ignition characteristics of living $Q$. mongolica leaves from various altitudes

\begin{tabular}{|c|c|c|c|c|c|c|c|}
\hline \multirow{2}{*}{ Items } & \multicolumn{7}{|c|}{ Altitudes (m) } \\
\hline & 900 & 1,000 & 1,100 & 1,200 & 1,300 & 1,400 & 1,500 \\
\hline Time to ignition (s) & 39 & 48 & 57 & $\begin{array}{l}\text { not } \\
\text { recorded }\end{array}$ & 14 & 59 & 25 \\
\hline Time to flameout (s) & 50 & 50 & 62 & $\begin{array}{l}\text { not } \\
\text { recorded }\end{array}$ & 16 & 75 & 29 \\
\hline Ignition temperature $\left({ }^{\circ} \mathrm{C}\right)$ & 280 & 290 & 275 & 299 & 278 & 306 & 308 \\
\hline
\end{tabular}

Table 3. Flame spread characteristics of living $Q$. mongolica leaves from various altitudes

\begin{tabular}{lccccccc}
\hline \multirow{2}{*}{ Items } & \multicolumn{7}{c}{ Altitudes (m) } \\
\cline { 2 - 8 } & 900 & 1,000 & 1,100 & 1,200 & 1,300 & 1,400 & 1,500 \\
\hline Average HRR $\left(\mathrm{kW} / \mathrm{m}^{2}\right)$ & 15.77 & 24.67 & 32.87 & 28.49 & 11.78 & 26.62 & 21.11 \\
Total heat release $\left(\mathrm{MJ} / \mathrm{m}^{2}\right)$ & 29.8 & 46.7 & 62.3 & 53.8 & 27.4 & 51.7 & 41.9 \\
\hline
\end{tabular}


measurements of $15.77 \mathrm{MJ} / \mathrm{m}^{2}, 24.67 \mathrm{MJ} / \mathrm{m}^{2}$, and $32.87 \mathrm{MJ} /$ $\mathrm{m}^{2}$, respectively. However, from $1,100 \mathrm{~m}$, the heat release decreased with altitude increase to $21.11 \mathrm{MJ} / \mathrm{m}^{2}$. Heat release was highest at approximately $1,100-1,200 \mathrm{~m}$. The outcome values are presented in Table 3.

\section{Smoke release}

\subsection{Total smoke release, maximum smoke density, and smoke temperature}

Fig. 4 shows the TSR curve for 50-g samples and Fig. 5 presents the maximum smoke density curve. The highest TSR was $220.02 \mathrm{~m}^{2} / \mathrm{m}^{2}$ from the $900 \mathrm{~m}$ sample, which was 2.5 times higher than the $87.50 \mathrm{~m}^{2} / \mathrm{m}^{2}$ released by the $1,000 \mathrm{~m}$ sample. Maximum smoke density was lowest in the $900 \mathrm{~m}$ sample, at $51.56 \mathrm{Ds}$, increasing to 65.47 Ds in the $1,200 \mathrm{~m}$ sample and thereafter increasing with altitude to $91.38 \mathrm{Ds}$.

Hence, high altitude forest fires will release more smoke, greatly reducing visibility, as compared to fires at

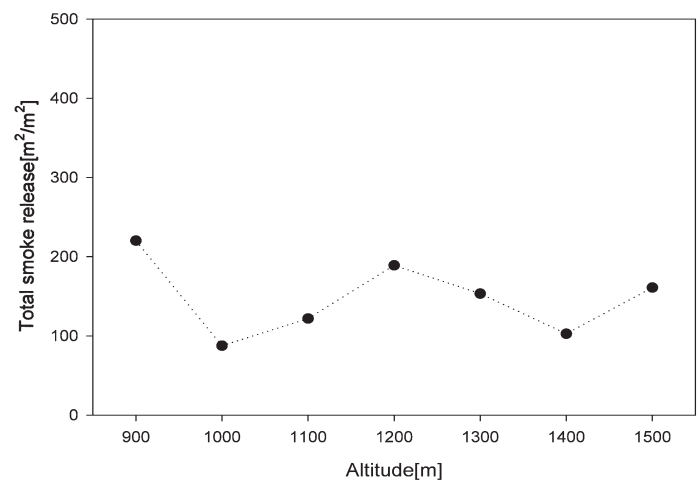

Fig. 4. Total smoke release of living $Q$. mongolica leaves from various altitudes.

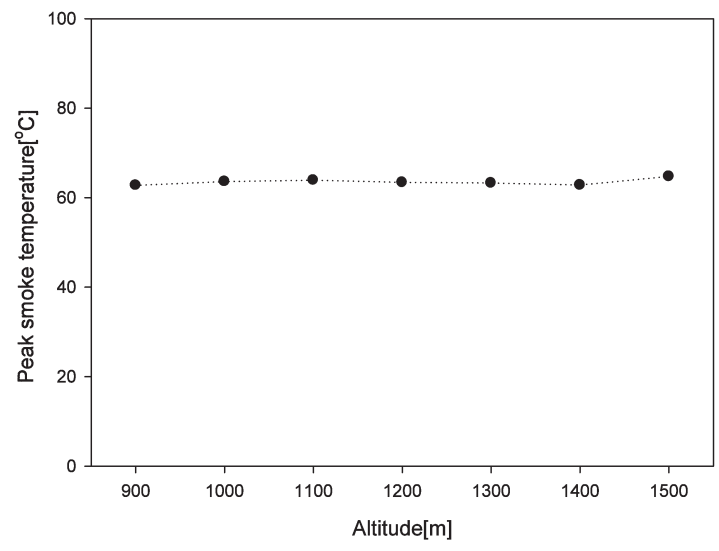

Fig. 6. Smoke temperature of living $Q$. mongolica leaves from various altitudes. low altitudes. Fig. 6 shows the peak Tss of combustion. The range of maximum Ts was $63-65{ }^{\circ} \mathrm{C}$, with no variation according to altitude. Outcome values are presented in Table 4

\section{2. $\mathrm{CO}$ and $\mathrm{CO}_{2}$}

Fig. 7 shows the mean release densities of $\mathrm{CO}$ and $\mathrm{CO}_{2}$ for $50 \mathrm{~g}$ of living $Q$. mongolica leaves with altitude variation. The mean release density of CO rose gradually, which suggests that as the altitude increases, smoldering occurs, rather than complete combustion, yielding more $\mathrm{CO}$. The mean release density of $\mathrm{CO}_{2}$ shows no consistent variation with altitude, but density increases with increasing altitude from 1,200 m.

The combustion products of $\mathrm{CO}$ and $\mathrm{CO}_{2}$ were produced at higher temperatures, after being pyrolyzed from cellulose, the main component of the leaves, into organic aldehyde or organic acid (Lee, 2005). Smoke and combustion products, yielded from fuel combustion, change

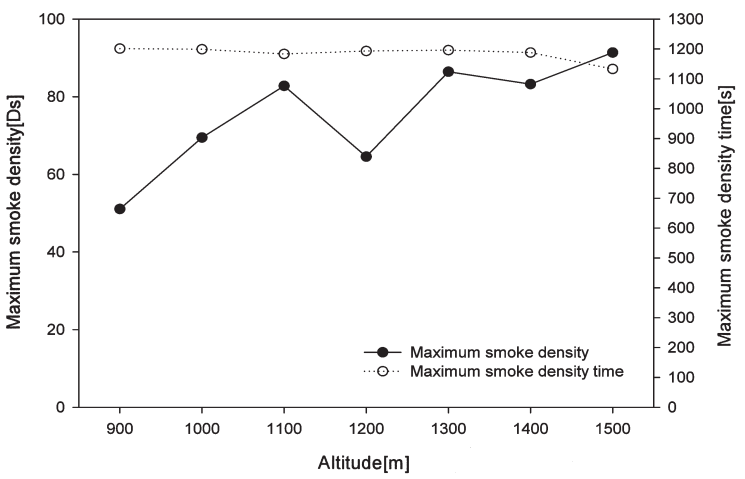

Fig. 5. Smoke density of living $Q$. mongolica leaves from various altitudes.

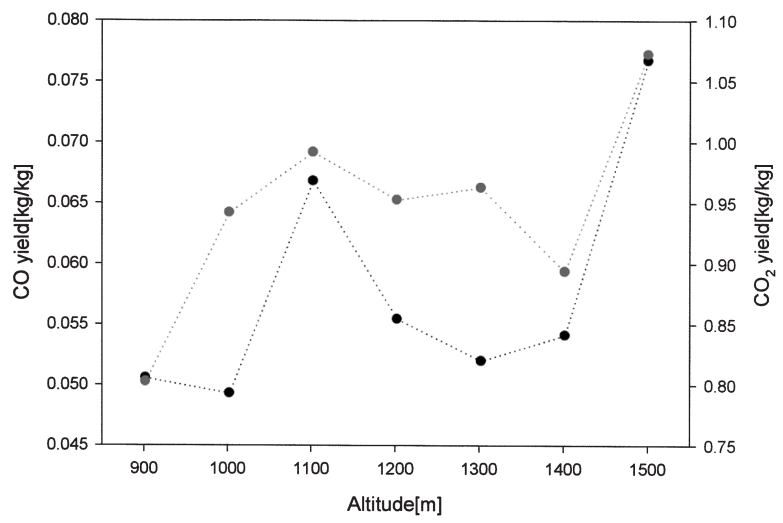

Fig. 7. $\mathrm{CO}$ and $\mathrm{CO}_{2}$ yields of living $Q$. mongolica leaves from various altitudes.

Table 4. Smoke release characteristics of living $Q$. mongolica leaves from various altitudes

\begin{tabular}{lccccccc}
\hline & \multicolumn{5}{c}{ Altitudes (m) } \\
\cline { 2 - 7 } Items & 900 & 1,000 & 1,100 & 1,200 & 1,300 & 1,400 & 1,500 \\
\hline Total smoke release $\left(\mathrm{m}^{2} / \mathrm{m}^{2}\right)$ & 220.02 & 87.5 & 121.9 & 189.1 & 153.3 & 102.6 & 160.89 \\
Peak smoke temp. $\left({ }^{\circ} \mathrm{C}\right)$ & 61.23 & 61.42 & 61.07 & 62.01 & 63.46 & 63.8 & 63.89 \\
Max. smoke density (Ds) & 51.06 & 69.48 & 82.8 & 64.57 & 86.45 & 83.25 \\
Max. ds time & 1,201 & 1,199 & 1,183 & 1,193 & 1,196 & 1,188 & 1,133 \\
\hline
\end{tabular}


Table 5. Concentrations of combustion gases for living $Q$. mongolica leaves from various altitudes

\begin{tabular}{lccccccc}
\hline \multirow{2}{*}{ Items } & \multicolumn{7}{c}{ Altitudes (m) } \\
\cline { 2 - 8 } & 900 & 1,000 & 1,100 & 1,200 & 1,300 & 1,400 & 1,500 \\
\hline Average CO yields & 0.0651 & 0.0568 & 0.0785 & 0.0644 & 0.0906 & 0.1226 & 0.0891 \\
Average $\mathrm{CO}_{2}$ yields & 1.06 & 0.99 & 1.23 & 0.93 & 1.03 & 1.16 & 1.18 \\
\hline
\end{tabular}

according to aspects of fire progress. Accordingly, the density and toxicity of smoke must be considered apart from other factors (Lee, 1993). Experimental conditions are presented in Table 5.

\section{CONCLUSIONS}

In this study, a series of experiments were conducted on living leaves of $Q$. mongolica to compare the combustion characteristics of fuel with varying altitude. The conclusions are as follows.

1) Moisture content measurement showed that living $Q$. mongolica leaves from Mt. Taeback had moisture contents of $117-145 \%$. Samples from altitudes of 900, $1,000,1,100,1,200,1,300,1,400$, and 1,500 m had moisture contents of $120.44,130.71,131.88,139.90$, $117.35,116.45$, and $144.72 \%$, respectively. Samples from $1,300 \mathrm{~m}$ and $1,400 \mathrm{~m}$ had slightly lower moisture contents.

2) Ignition characteristics varied little between altitudes, with non-flame temperatures of $275-308^{\circ} \mathrm{C}$. Samples from $1,100 \mathrm{~m}$ and $1,300 \mathrm{~m}$ had relatively low nonflame temperatures. TTI tests showed that $1,300 \mathrm{~m}$ and $1,500 \mathrm{~m}$ samples ignited faster than the other samples, but the flames faded after 2 and 4 seconds, respectively. Conversely, the $1,400 \mathrm{~m}$ sample had a TTI of 59 seconds, but maintained a flame for the longest of all samples. Although flame ignition of the 1,200 m sample was not observed, the high heat release and TSR indicate that non-flame ignition occurred.

3) Fire characteristic tests showed that THR was $30-62 \mathrm{MJ} / \mathrm{m}^{2}$, and the mean HRR was $12-33 \mathrm{~kW} / \mathrm{m}^{2}$. Up to $1,100 \mathrm{~m}$, heat release increased with altitude to $32.87 \mathrm{MJ} / \mathrm{m}^{2}$. However, above $1,100 \mathrm{~m}$, heat release decreased to $2.11 \mathrm{MJ} / \mathrm{m}^{2}$. The highest heat releases were recorded for samples from 1,100 $\mathrm{m}$ and 1,200 m.

4) Smoke characteristic tests showed that the TSR was highest at $900 \mathrm{~m}\left(220.02 \mathrm{~m}^{2} / \mathrm{m}^{2}\right)$, which was 2.5 times more than the total smoke released from the $1,000 \mathrm{~m}$ sample $\left(87.50 \mathrm{~m}^{2} / \mathrm{m}^{2}\right)$. Maximum smoke density was lowest at $900 \mathrm{~m}$ (51.06 Ds) and increased with altitude to 91.38 Ds, which means that more smoke was released at the start of combustion with increased altitude.

5) Tests of the release densities of combustion products $\mathrm{CO}$ and $\mathrm{CO}_{2}$ showed that the mean release density of CO rose with increasing altitude, while the density of $\mathrm{CO}_{2}$ rose from $1,200 \mathrm{~m}$ with increasing altitude.

\section{ACKNOWLEDGEMENTS}

This study was carried out with the support of
'Forest Science \& Technology Projects (Project No. S210809L010130) provided by Korea Forest Service.

\section{REFERENCES}

ASTM E 6622003 Test method for specific optical density of smoke generated by solid materials.

Davis, K. P. and A. A. Brown 1959 Fire in the forest in: FOREST FIRE control and use second edition, Mc Graw-Hill: 3-259

Gangwon Provincial Police Agency 2002 Gangwon local officials training instutute. Forestry Resources Application Process: 6-8 (In Korean)

Hong, Y. M. and G. S. Jung 1992 Safety engineering experiment. Donghwa Technology: 9-11 (In Korean)

ISO 5660-1 2002 Reaction to fire part 1. Rate of heat release from building products (Cone Calorimeter). Generer.

ISO 5660-2 2002 Reaction-to-fire tests-Heat release, smoke production and mass loss rate-Part 2: Smoke production rate (dynamic measurement).

Jung, J. S., B. D. Lee and H. H. Kim 2002 Estimation of Pinus densiflola stand damage grades for Samcheok forest fire area using GIS and discriminate analysis. Journal of the Korea Association of Geographic Information Studies 91(3): 355-361 (In Korean with English abstract)

Kim, D. H., J. S. KO, S. W. Choi and K. I. Kim 1999 A study on fire investigation \& calorie analysis of main trees in Go-sung wildfire land. Journal of the Korean Institute of Fire Science \& Engineering 13(1): 31-33 (In Korean with English abstract)

Kim, D. H., M. B. Lee, Y. H. Kang and S. Y. Lee 2006 The Analysis of forest fire hazard of a surface fuel through Ignition Test. Proceedings of The Korea Society of Hazard Mitigation Conference: 379-384 (In Korean with English abstract)

Kim, H. J., Y. K. Eum, J. J. Yi, H.S. Jung and Y. K. Choi 2004 An introduction to timber engineering. Donghwa Technology: 33-34 (In Korean)

Kim, K. S., I. S. Jang, K. D. Park and S. J. Kim 1995 Burningtemperature change of living branches and leaves of Pinus rigida and Larix leptolepis. Journal of Korea Ecology and Field Biology 18(3): 333-340 (In Korean with English abstract)

KS F 22711998 Testing method for incombustibility of internal finish material and element of buildings (In Korean)

Lee, B. G 2005 Introduction to forestry engineering (I) Yeungnam University publishing: 161-163 (In Korean)

Lee. B. Y. 1993 Studying on smoke and smoke detection technology. Korean Fire Protection Association. Disaster Prevention Technology 15: 28-38 (In Korean)

Lee, S. Y. 2004 Forest fire prevention system of foreign. National Institute for Disaster Prevention. Disaster Prevention Research 6(4): 25-33 (In Korean)

Park, H. J., E. S. Kim, J. H. Kim and D. H. Kim 2007 A combustion characteristic analysis of Quercus variabilis and Pinus densiflora fallen leaves using radiation heat flux. Journal of the Korean Institute of Fire Science \& Engineering 21(3): 41-46 (In Korean with English abstract)

Shim, J. S., et al. 1994 Forest Chemistry. Hyangmoonsa: 137-145 (In Korean)

Yim. K. G. 2007 Forestation theory. Hangmoonsa: 47-50 (In Korean) 